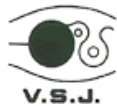

\title{
投影型複合現実感技術を用いた熱画像可視化*
}

\author{
岩井 大輔 1), 佐藤 宏介 2 )
}

\section{Thermal Image Visualization \\ in Projection-Based Mixed Reality}

\begin{abstract}
This paper presents a novel visualization method of thermal image through projection-based mixed reality (MR) technologies. In the proposed method, geometrically adjusted and photometrically compensated projection light of thermal image is optically superimposed onto a real object. Users can intuitively recognize temperature distribution of the object since it is appeared onto the object itself in real space, not a two dimensional monitor. When the temperature distribution information of the object is displayed on a monitor, users often have to look the monitor and the object scene alternately to obtain geometrical relations between the thermal image and the object. This kind of spatial seam between a display space (a monitor) and an object space (a real space) causes psychological difficulty in usability. To unify these two spaces seamlessly, the authors believe that the spatial consistency is the key for realizing the user's intuitive understanding of the object's temperature distribution.
\end{abstract}

Daisuke IwAI and Kosuke SATO

Keywords : Projection-based mixed reality, Thermal image, Human-computer interface

\section{1. はじめに}

熱情報を媒介する特殊な波長域である遠赤外領域の光 を捉えることのできる赤外線カメラは, 対象物体の温度情 報を非接触で 2 次元画像として可視化することが可能で あり，これまで検査・医療・災害救助といった分野での利 用がなされてきている 1 . エースの観点から見ると, 赤外線カメラによって撮影され た温度分布が, 対象物体のどの部分と対応しているのかを, その熱画像のみから認識することは容易ではないという 問題がある. 温度分布と対象物体との幾何学的対応を把握 するには, ユーザは熱画像と対象物体との間で目視による 比較を行わなければならない.このため, 多くの赤外線力 メラには液晶モニタのような画像提示装置が取り付けら れており, ユーザは対象物体の可視画像と熱画像とを交互 に見比べることでようやくその対応を把握することが可 能となっていた.

筆者らは, このユーザインタフェース上の問題を解決す る，投影型複合現実感(MR: Mixed Reality)技術を用いた

* 原稿受付 2006 年 8 月 29 日

1) 正会員 大阪大学 大学院基䃈工学研究科, 日本学術振興会特 別研究員 DC2（广560-8531 大阪府豊中市待兼山町 1-3, Email : iwai@sens.sys.es.osaka-u.ac.jp)

2) 非会員 大阪大学 大学院基礎工学研究科
熱画像の新たな可視化手法を提案する. 提案手法ではまず 赤外線カメラから取得された熱画像に幾何学補正 (位置合 わせ）処理・色補正処理を施す．次にこれをプロジェクタ から直接実世界の対象物体に投影し光学重畳することで, ユーザに対象物体の温度分布情報を提示する.これによっ て「「ディスプレイ空間」(熱画像を提示する空間）と「対 象空間」（対象物体の存在する空間）とが 3 次元空間の中 で一致し, 実対象物体上でより直観的にその温度分布を把 握することが可能となる.

本論文ではまず, モニタ上で熱画像を提示するシステム の問題点を挙げる. 次に, 提案する投影型 MR 技術を用い た熱画像投影について述べた後, システムの構成とその幾 何学・色補正処理方法について述べる. そして, 実機でシ ステムを構築し, 補正処理の有効性を確認する基礎実験と, 提案手法のユーザインタフェースとしての有効性を示す 4 種の応用実験を行う. 最後に, 実験に関する考察を行い 今後の展望を述べる.

\section{2. モニタを利用した熱画像提示の限界}

通常, 赤外線カメラに取り付けられている液晶モニタや 外部の画像提示装置を用いて, ユーザは熱画像と対象物体 とを比較し，その温度分布を把握する．この作業をより容 易に行うために, 赤外線カメラの隣に可視カメラを取り付 け, 熱画像と同じシーンを可視画像として取得してユーザ 
Table 1 Configuration of projection system for static/dynamic object.

\begin{tabular}{c|cccc}
\hline 対象 & システム構成機器 & 配置 & 幾何学補正 & 色補正 \\
\hline 静止物体 & プロジェクタ・赤外線カメラ・可視カメラ & 任意 & 3 次元形状計測による位置合わせ & 可 \\
動物体 & プロジェクタ・赤外線カメラ & 光軸一致 & ホモグラフィ変換 & 不可 \\
\hline
\end{tabular}

に提示したり,レーザポインタで撮影している場所を指し 示したりするような工夫もなされてきている. また最近で は, 同じシーンを撮影した可視画像と熱画像とをモニタ上 で重畳してユーザに提示することで, 温度分布と対象物体 との幾何学的対応が一目で把握できるようなシステムも 市販されてきている.しかしながら，このようなインタフ エースの改善にもかかわらず, モニタを利用した熱画像提 示は，ディスプレイ空間と対象空間が一致しないために， 以下に示すような状況において有効ではない.

（1） 空間的な偏りのないシーンを対象とする場合

（2）対象物体が立体物である場合

（3）対象物体が動いている場合

（4）対象物体の温度分布を把握しながら作業を行う場合

（5）対象物体を用いて対面協調作業を行う場合

項目 1 は，同じ形をした物体が多く敷き詰められてい るようなシーンを対象とする場合や, 真っ白な壁のように 対象物体の位置を特定する手掛かりが全くないような場 合を指す。このような状況では，ユーザが温度分布把握後 の作業へと即座に移行できないという問題が生じる. 例え ば非破壊検査で，モニタ上で対象物体の温度異常個所を検 出する場合, たとえモニタ上で幾何学的に対応の取れた対 象物体の温度分布を把握できたとしても，モニタ上の対象 と実世界の対象との幾何学的な対応をとることが困難で あるために, 即座にその異常個所を現場で特定することは 難しい.

項目 2 のように，対象物体が立体物である場合でもモ ニタ上では温度分布は 2 次元画像として提示される.この ため, 対象表面の温度分布を立体的に把握することは困難 となる。

項目 3 のように対象物体が動いている場合では, 視線 がモニタと対象物体との間を行き来する遅延時間が問題 となる.モニタ上で温度分布を確認したときに撮影されて いた対象シーンは, ユーザが視線をモニタから移したとき にはもう変化しており, モニタ上の対象と実世界の対象と の幾何学的対応をとることが難しく, 項目 1 のように，そ の後の作業へと即座に移行することが困難となる.

項目 4 は，対象物体の温度分布が作業にとって重要な 情報である場合を指す。このとき，ユーザは作業対象を注 視しなければならないが, 同時にモニタ上の温度分布を確 認しなければならず，作業を効率的に行うことはできない. 項目 5 で記した状況とは, 同じ場所にいる複数人の作
業者が対象物体の温度分布を見ながら議論をするような 場面を指す.モニタを介する対面協調作業インタフェース では，実世界の「対話空間」とコンピュータ内の「作業空 間」（ディスプレイ面）が乘離してしまう。例えば，一つ の共有モニタに向かい作業者が横並びになる場合, 作業者 の主な注意は作業空間であるディスプレイ面に向けられ， 対話空間にはそれほど注意は向けられない2), 3).このため, モニタを用いた作業形態では, コンピュータを用いない対 面協調作業と比較して, 作業者間の対話空間において, 視 線やジェスチャなどのノンバーバル（非言語的）な対話の 手がかりの共有が減少し, 円滑なコミュニケーションが阻 害されるため，作業の効率が低下寸る.

\section{3. 温度分布投影システム}

投影型 MR 技術は，プロジェクタを用いて仮想データ を実世界の物体に投影重畳することで，シームレスに仮想 空間と物理空間とを融合する可視化技術である.モニタや HMD (Head Mounted Display)上で仮想像を実像と重畳 するビデオシースルー型・光学シースルー型の MR 技術と 異なり，実対象を直接観察することができるため，立体感 も含めた対象の存在感が損なわれない. また, 複数のユー ザが同時に複合現実感覚を享受することができる.

本研究では，この投影型 MR 技術を用いて，熱画像を 直接対象物体上に投影重畳し，その温度分布を直観的に把 握できるシステムを構築する. ディスプレイ空間と対象空 間とが一致し, 熱画像と対象物体とを見比べる必要がなく なることで，2 章で述べた問題点を解決することができる.

提案する可視化処理の流れを以下に示す.まず, 赤外線 カメラより対象物体の熱画像を取得する.次に, この熱画 像（グレイスケール画像）を，疑似カラー表示 (赤 $\Leftrightarrow$ 青) に変換する，そして，位置合わせのための幾何学補正処理 と, 対象物体上で任意の色の見えを実現するための色補正 処理を施して投影画像を生成し, プロジェクタより投影す る.

対象物体が静止しているか, 動いているかで, システム 構成や，幾何学・色補正手法が異なる（Table 1). 以下で は，それぞれの場合についてのシステムの構成と補正処理 について述べる.

\section{1 静止物体を対象とするシステム}

対象物体が静止している場合, 温度分布を取得する赤外 線カメラ，熱画像を投影するプロジェクタ，そして，色補 正処理で利用する可視カメラの 3 要素でシステムを構成 する.これらの機器は, 任意の位置に設置することが可能 
である。

\section{（a）幾何学補正}

対象物体上の正確な位置にその温度分布を重畳表示す るために, 赤外線カメラとプロジェクタの画素間の対応付 け（幾何学的キャリブレーション）を行う必要がある。ま た, 色補正処理のために, 可視カメラの画素との対応付け も行わなければならない. Fig.1 に, 対象物体を観測する 可視カメラ座標系, 熱画像を取得する赤外線カメラ座標系, 温度分布を投影するプロジェクタ座標系, および世界座標 系の関係を示す.

本研究では, グレイコードパターン投影法 4),5)を用いて 幾何学的キャリブレーション（較正）を行う。較正用の基 準物体として各面に基準点が描かれた一辺 $160[\mathrm{~mm}]$ の立 方体を用いる（Fig.2（a)). まず，グレイコードパターン をプロジェクタより投影し，その像を可視カメラで観察す ることで可視カメラとプロジェクタの較正を行う

(Fig.1 (1), (2)).

次に, 赤外線カメラの較正を, 同じ較正用基準物体を用 いて行う (Fig.1 (3)). このとき, 赤外線カメラからは基 準点を認識することができないため, 基準物体の裏側に豆 電球を取り付けて暖めることで立方体の七隅 (世界座標既 知）の温度が高くなる (Fig.2 (b), (c)). この熱画像中の輝 度の高い点の座標值をそれぞれ手動で取得することで, 赤 外線カメラの較正を行う. 次に, 基準物体を計測対象に取 り替え, プロジェクタより縦か横のグレイコードパターン を投影し, その像を可視カメラで得ることで対象物体の形 状を計測する. 最後に, 対象物体の 3 次元形状データおよ び Fig.1 (1), (2), (3)の較正結果を用いることで, 可視カメ ラ, プロジェクタ, 赤外線カメラそれぞれの間での座標值 の対応が求められる（Fig.1 (4), (5), (6)).

\section{（b）色補正}

温度分布を投影する際に, 対象物体の反射特性や環境光 の影響から, 望むべき表示色が得られなくなることが問題 となる. 例えば, 対象物体のテクスチャを残したまま温度 分布を対象に投影すると, ユーザは対象表面に表示されて いる色分布が，投影された温度分布を表しているのか，そ れとも対象自身のテクスチャであるのかを判別できなく なる可能性がある. 特に, 対象のテクスチャを知らないユ 一ザが観察すると, 認知的に対象のテクスチャと投影温度 分布とを分離することが困難なために, このような誤解を 生じる可能性が高くなる.

この問題を解消寸るために, ユーザがまるで無地の対象 物体上に温度分布が投影表示されているかのように知覚 できるシステムとして, 投影光の色補正を行う。通常, 対 象物体の反射特性は空間的に均一ではないため, 色補正処 理は対象物体上の各部位毎に行わなければならない. 筆者 らは, 可視カメラとプロジェクタの色空間のアフィン相関 を求めることでこの問題を解決する手法を既に提案して

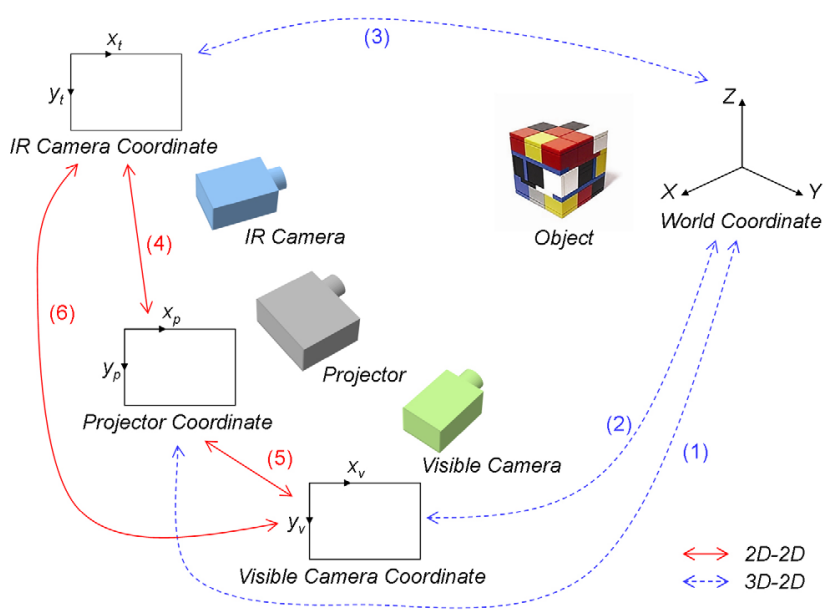

Fig.1 Coordinate system for static object.

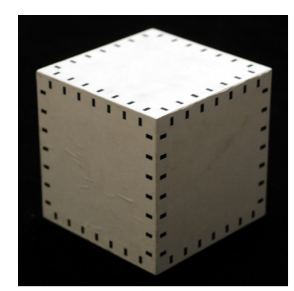

(a)

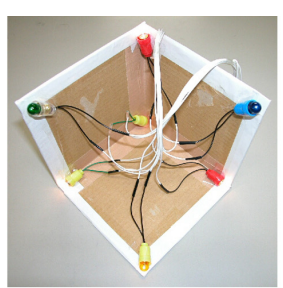

(b)

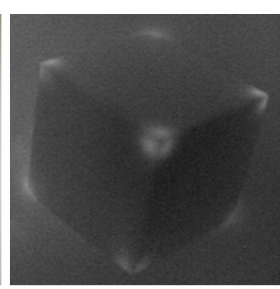

(c)
Fig.2 Calibration box.

( (a) outlook, (b) light bulbs, (c) thermal image )

いる ${ }^{6)}$. 本研究ではこの色補正手法を利用して対象物体上 で良好な温度分布重畳結果を得ることを目指す。

投影色 $\left(R_{p}, G_{p}, B_{p}\right)$ と，これを投影した際の対象上での 反射を可視カメラで観測した画素值 $\left(R_{c}, G_{c}, B_{c}\right)$ との関係 は, 環境光の影響を考慮して平行移動成分を加えた 3 行 4 列のアフィン変換行列 $K$ を用いて式(1)のように記述する ことができる。

$$
\left[\begin{array}{lll}
R_{p} & G_{p} & B_{p}
\end{array}\right]^{t}=K\left[\begin{array}{llll}
R_{c} & G_{c} & B_{c} & 1
\end{array}\right]^{t}
$$

色変換行列 $K$ は, 可視カメラ画素毎に求める. 可視力 メラ画素值 $\left(R_{c}, G_{c}, B_{c}\right)$ を目標色に設定することで, 式(1) より，この目標色を対象上で実現するための投影色 $\left(R_{p}, G_{p}\right.$, $\left.B_{p}\right)$ を対象物体の部位毎の反射特性, 照明環境に応じて算 出することができる.

色変換行列 $K$ を求めるために, 4 色以上の単一 $\mathrm{RGB}$ 光 をあらかじめ対象物体に投影し, その様子を可視カメラで 観測する.これにより投影光 RGB 值と可視カメラ RGB 值の対応関係が得られる.ここでは, 32 色の単一 RGB 光 を対象物体に投影し, 最小二乗法によって $K$ を算出する.

\section{（c）補正処理の流れ}

補正処理は, 全体として以下の流れで行う。まず, 赤外 線カメラによって取得された熱画像を可視カメラ座標系 へ変換する.この変換画像を目標画像として色補正処理を 
施す.この色補正後の画像を今度はプロジェクタ座標系へ 変換することで投影画像を生成する.

\section{2 動物体を対象とするシステム}

動物体を対象とする場合のシステム構成, 補正処理につ いて述べる. 3.1 で述べた幾何学補正手法では, 対象物体 が動くと再度その 3 次元形状を計測しなければならない が，グレイコードパターン投影法ではリアルタイムに対象 の形状計測を行なうことは困難であるため, 今回は用いる ことはできない. そこで, Fig.3 に示すように赤外線カメ ラとプロジェクタの光軸が同軸となるように設置し, 以下 で述べる手法を用いて幾何学補正処理を行う.

赤外線カメラとプロジェクタの光軸を同軸になるよう に設置すると, 画角の違いと光軸周りの回転方向のずれと いう， 2 種の位置ずれが生じるが，これを補正する幾何学 キャリブレーションを一度施すだけで, 対象物体が動いて も，正確な位置に熱画像を投影できるようになる．筆者ら はこの較正処理に, 赤外線カメラープロジェクタ座標系間 のホモグラフィを利用する.

ホモグラフィとは平面を異なる地点から撮影した場合 にその画像間に成立する射影関係のことである.この射影 関係を示す 3 行 3 列のホモグラフィ行列は, 対応する赤外 線カメラ座標值とプロジェクタ座標值を 4 組以上用いて 線形演算によって求めることができる. 本研究では, 赤外 線カメラで, 先述の較正用基準物体の平面を一つ撮影し, その四隅の座標值を手動で取得する。また，手動と目視に よって, その 4 点に投影されるプロジェクタ座標值を取得 する.

ホモグラフィ行列が得られると, 任意の赤外線カメラ座 標值に対応するプロジェクタ座標值が求められる. 提案す るシステムでは, 光軸が同軸になるように設置されている ことから, 一度ある平面で求められたホモグラフィ行列を 用いることで, 3 次元空間中のどの点においても双方の座 標值の対応関係を得ることができる.

色補正処理に関しては，3.1で述べた手法では，対象物 体が動くたびに色変換行列 $K$ を求めなければならないが, 較正のために単一 RGB 光を 4 色以上対象に投影する必要 があるため, リアルタイムに処理を行うことができない. このため, 動物体を対象とする場合には色補正処理は行な わないこととし，可視カメラは用いない.

\section{4. 温度分布投影実験}

本章では, 3 章で提案した温度分布投影システムを構築 し，対象物体一の温度分布の投影実験を行う. 実験として はまず，提案する幾何学・色補正処理の有効性を確認する ための基礎実験を行う. 次に, 構築したシステムを用いて, 2 章で述べたモニタを介する温度分布提示の問題点に対 して, 提案手法が有効な解決策であることを示す 4 種の応 用実験を行う.

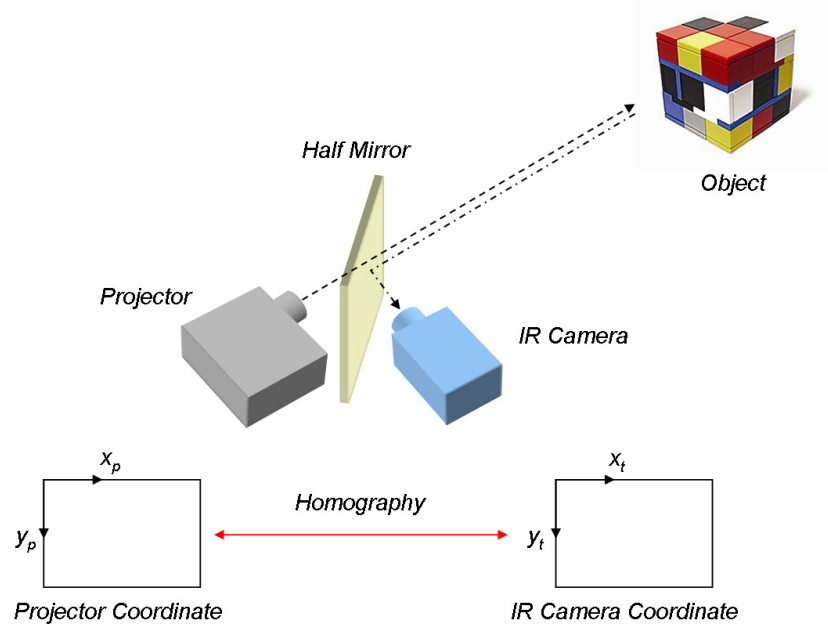

Fig.3 Coordinate system for dynamic object.

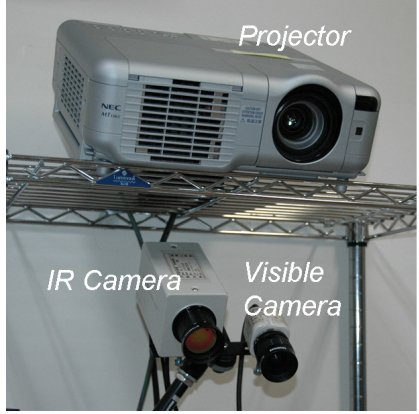

(a)

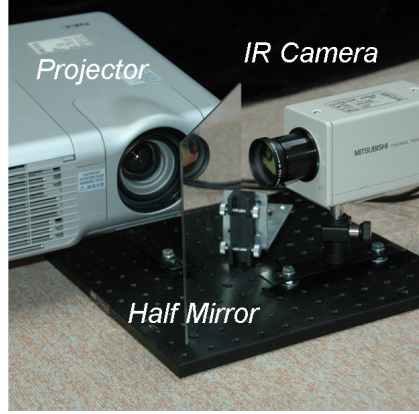

(b)
Fig.4 Outlook of experimental systems. ( (a) STATIC system, (b) DYNAMIC system )

\section{1 実験環境}

静止物体, 動物体を対象とするそれぞれの実験環境を Fig.4 に示す.ここで, それぞれのシステム名を STATIC, DYNAMIC とする.それぞれのシステムで使用される機 器は, 赤外線カメラ(Mitsubishi IR-SC1), ビデオプロジ エクタ (NEC MT1075J, 輝度: 4200[lm]), 可視カメラ (Tokyo Electronic Industry CS5850)である.これらの機 器は, PC(CPU: Intel Pentium4 2.5[GHz])1 台によって制 御される。なお，DYNAMIC システムでは赤外線カメラ とプロジェクタの光軸を同軸にするため, 赤外反射・可視 透過のハーフミラーを用いる. また，可視カメラとプロジ エクタの入出力特性はあらかじめ線形にしておき, 画素值 の範囲を 0-255 とする.

\section{2 基礎実験}

幾何学・色の両補正手法に関して有効性を確認するため の基礎実験を行う。実験の対象として, 空間的に変化のあ る反射特性をその表面にもつ，温水（約 $60^{\circ} \mathrm{C}$ ）の入った 半径 $40[\mathrm{~mm}]$ 高さ $95[\mathrm{~mm}]$ のコップを用意し, 実験室の床 面に置く. STATIC システムは，床面を見下ろす形でその 上方 $900[\mathrm{~mm}]$ に設置する．このとき，床面での環境光の 
輝度值と, そこへプロジェクタより白色を投影した際の輝 度值を測定した．分光放射計(TOPCON SR-1)を用いて， 床面に置いた標準カラーチャート（GretagMacbeth 社 ColorChecker）の white 領域上で測定を行った. その結

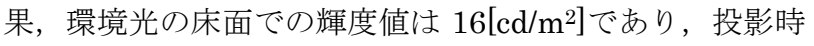

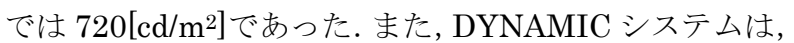
床面に設置した.

STATIC システムでの熱画像投影結果を Fig.5 に示す. 同図(a)は，可視カメラで取得された投影前の環境光下で の対象の見えである. 同図(b)は, 同時に赤外線カメラで 取得された同シーンの温度分布である.この熱画像を可視 カメラ座標系に変換したものが, 同図(c)であり, これが目 標画像となる。同図(d)は, この目標画像に色補正処理を 施し，プロジェクタ座標系に変換した投影画像である。同 図(e)は，この投影画像の投影結果である. 同図(f)は，色補 正処理を施さずに温度分布を投影した結果である。なお， これらの図は全て対象付近を抜粋し拡大したものである. この結果より, 熱画像が位置合わせされて対象物体に投影 されていることが確認できる，また，色補正の結果，熱画 像をそのまま投影した場合に比べて, 投影面（対象物体表 面）のテクスチャの影響が軽減されていることが確認でき る. 目標色との RGB 值の差の画素平均值は，色補正有の 場合で 69, 無の場合で 116 であった.

DYNAMIC システムで, 対象物体を動かして, 熱画像 を投影した結果を Fig.6に示す。同図より，対象が動いた 場合でも, 熱画像が位置合わせされて投影されていること が確認できる。フレームレートは $30[$ frame/sec]で，リア ルタイムに温度分布を動物体に重畳できることが確認で きた.

同図(c)において，コップの口の部分に黒い縁取りが生 じており，それが投影結果にも影響を与えていることが確 認できる.これは, 位置合わせを行う 2 種の光学系が空間 的に異なる位置に存在することにより起因する不可避な 問題である. 提案するシステムでは, 可視カメラでは観察 できるが赤外線カメラからは観察できない領域が対象上 に必ず生じてしまう。このため, このような領域の熱画像 は, 座標変換後の可視カメラ座標系では黒く抜けてしまう. この問題は, 可視カメラと赤外線カメラの光軸を同軸とな るように設置するか, 複数の可視カメラ・赤外線カメラを 用意することによって解決することができる.

\section{3 応用実験}

応用実験として, 整然と敷き詰められた絵具チューブの 中から中身が空のチューブを見つけ出す実験, 白壁の裏側 にある鉄筋を見つけ出す実験, 対面協調作業を支援する環 境の一例としてノート型 PCの熱設計を議論する場の構築 と動作確認実験, そして, 身体の温度分布を投影寸るシス テムの構築とその動作確認実験を行う. 本節で示す実験は 全て DYNAMIC システムを用いて行なった。

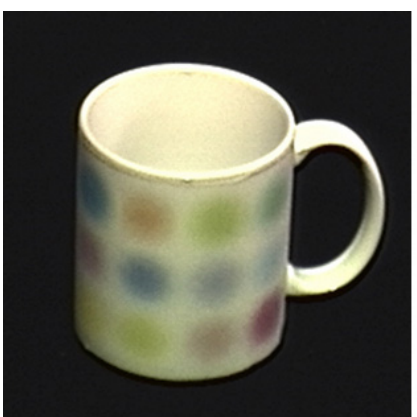

(a)

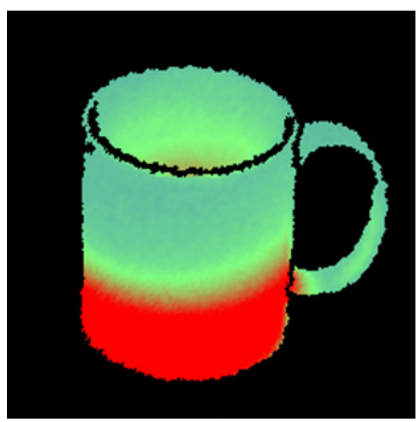

(c)

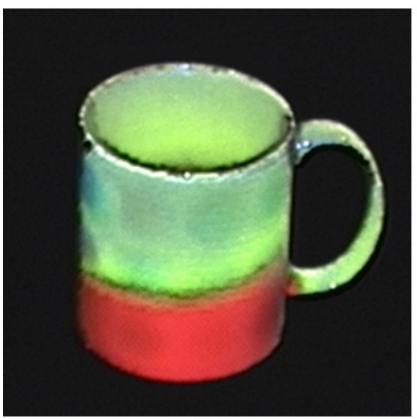

(e)

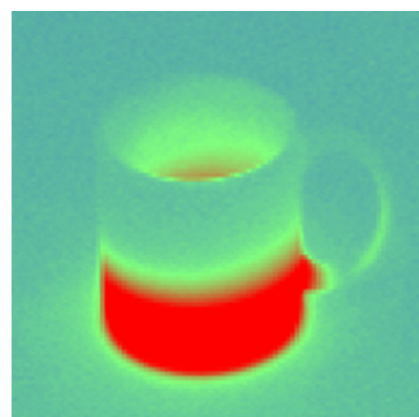

(b)

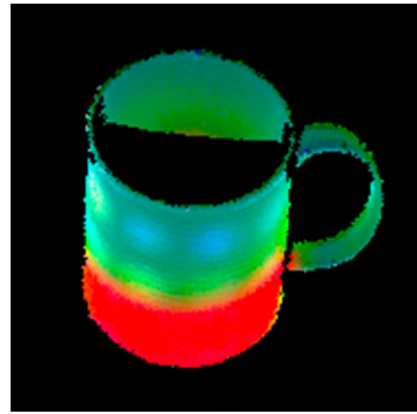

(d)

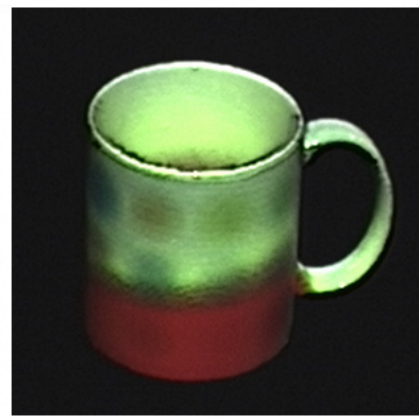

(f)
Fig.5 Experimental results of STATIC system. ( (a) normal appearance of object captured by visible camera, (b) thermal image, (c) target image, (d) projection image with color compensation, (e) projection result with color compensation, (f) projection result without color compensation )

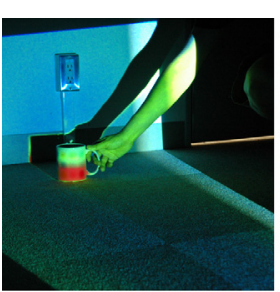

(a)

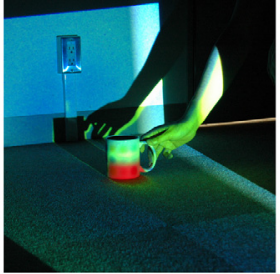

(b)

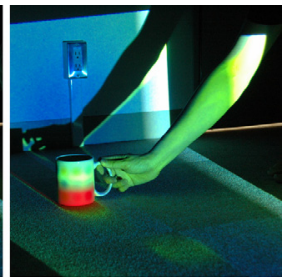

(c)
Fig.6 Experimental results of DYNAMIC system.

\section{（a）空の絵具チューブを見つける実験}

試料内に存在する久陷を見つけ出す赤外線カメラを使 った非破壊検査では，一旦試料を加熱し，その後の表面温 度の冷却過程を熱画像として取得することで行われるこ とがある 7).そこで今回，このような検査での用途を考慮 
して，提案するシステムを使って，同じ形をした絵具チュ 一ブが敷き詰められている中から, 絵具が入っていない空 のチューブを見つけるという実験を行う. 絵具チューブの 上から，ヘアドライヤを使って温風を吹きつけ，その後の 温度変化を観察する.

赤外線カメラより得られた熱画像をプロジェクタより 投影する場合と，モニタ上で確認する場合での実験結果を Fig.7 に示す，モニタ上では，温度の低下が他よりも遅い チューブ(空のチューブ)があることは確認できるものの， それがどのチューブであるのかを特定することは困難で ある.これに対して提案システムの方では，対象上に直接 温度分布が重畳投影されているため, 一目で他と異なるチ ユーブがどれであるのかを特定することが可能であるこ とが確認できる。これによって，温度分布把握後，即座に 空の絵具チューブを取り出すことが可能となる.

\section{（b）白壁の裏側の鉄筋を可視化する実験}

建築物の外壁診断や空調診断に赤外線カメラはよく用 いられる。これは，普段目には見えない建物の内部構造の 問題点を見つけ出すために行われるが，壁や天井は，空間 的に変化のない場合が多く, モニタ上で確認しただけでは 熱画像と対象との幾何学的対応をとることは難しい. そこ でこのような状況において, 提案システムが有効であるこ とを示すため, 真っ白な壁の裹側にある鉄筋の様子を可視 化する実験を行う.

空調装置の冷風の噴出し口に面した白壁の温度分布を 可視化した. 鉄筋は他よりも熱伝導率が高く, 外気温（室 内よりも高温）が伝わることから，壁表面のうち，鉄筋に 接している部分は周りよりも温度が高くなる．Fig.8に， 壁に温度分布を直接投影した場合と, モニタ上で温度変化 を観察した場合の結果を示す，先ほどの実験と同様に，モ 二タ上で温度分布を確認しても対象との対応がとれない のに対し, 提案システムでは, 温度分布が対象上に浮かび 上がるため, 対象の温度分布から鉄筋の位置を容易に特定 することが可能となる.

\section{（c）ノ一ト型 PC の熱設計を議論する対面協調作業 環境の構築}

提案システムを用いた対面協調作業の一例として,ノー 卜型 PC上に投影された温度分布を確認しながら熱設計の 検討を行うことのできる環境を構築し, 動作確認実験を行 う. 2 章で述べたように, モニタ上で対象の温度分布を共 有すると, 対話空間ではなくモニタ上のデータに注意が向 けられるため, 効率の良い協調作業が行われなくなる。こ の実験では, 対話の手がかりとなるノンバーバル情報の豊 富な，コンピュータを用いない通常の対面協調作業の作業 形態を崩すことなく, 対象の温度分布情報を投影提示し協 調作業を支援する.

机上にノート型 PC (Apple iBook G4) を置いて, 温度 分布を投影重畳した（Fig.9）。このシステムでは，机上

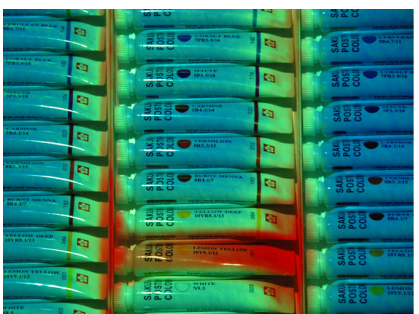

(a)

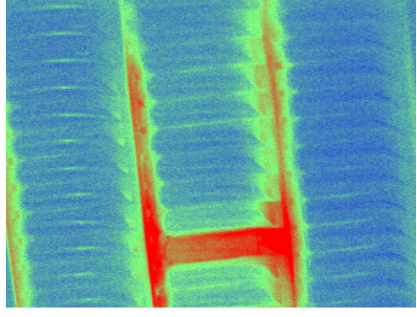

(b)
Fig.7 Temperature distribution of paint tubes.

( (a) projection result, (b) thermal image )

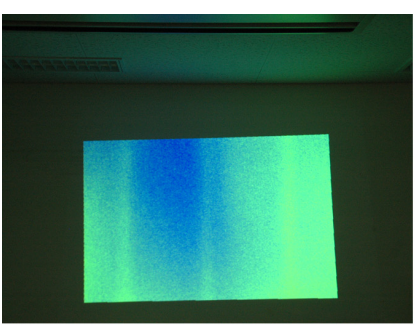

(a)

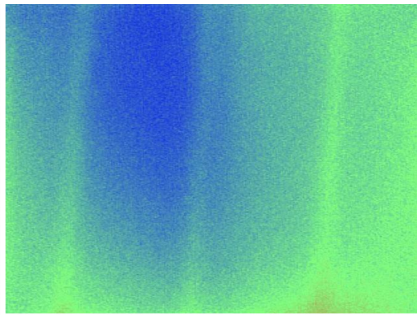

(b)
Fig.8 Temperature distribution of plain wall.

( (a) projection result, (b) thermal image )

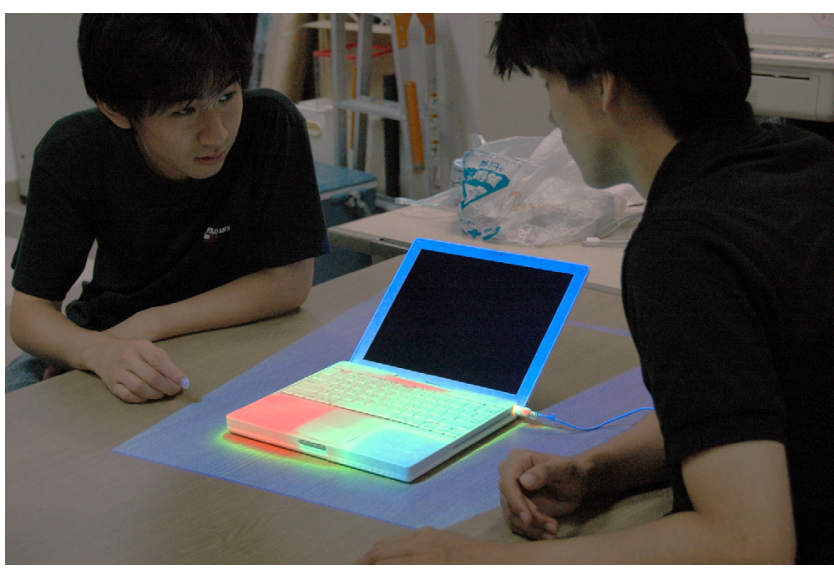

Fig.9 Face-to-face collaboration with thermal image projection.

を取り囲んだユーザが，筐体を直接指差すことができたり， 向かい合って議論することができる．これによって，活発 なコミュニケーションが促進され, 効果的な対面協調作業 を行なうことができるようになる，

\section{(d) 身体への温度分布の投影}

赤外線カメラによって撮影される身体の温度分布情報 は, 医療現場での検診用に用いられる. 今後, 赤外線カメ ラの小型化・低価格化が進むと, 一般の家庭に普及してい くことが考えられる. そのような状況における一応用例と して, 各家庭において, 自分自身の健康チェックを行うこ とのできるシステムを提案する。 このシステムでは, 赤外 線カメラによって撮影された温度分布を直接身体に投影 重畳することで, ユーザは自身の身体の温度分布を直観的 に把握することができる。

人は, 自分の顔をはじめ身体に投影されている温度分布 


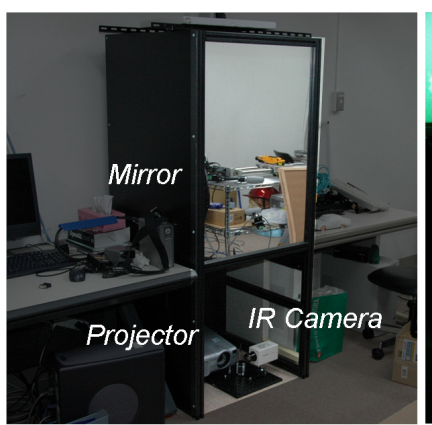

(a)

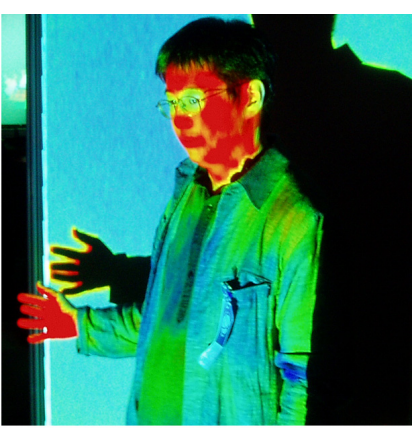

(b)
Fig.10 Projection of temperature distribution onto own body.

( (a) system overview, (b) projection result)

を見ることは困難である，そこで，DYNAMIC システム をユーザ (対象物体) へ向けて設置するとともに, 自分の 体に投影されている温度分布をより容易に把握すること ができるように，ユーザの前に鏡を置く（Fig.10(a))。今 回の実験では $900 \times 600[\mathrm{~mm}]$ の鏡を使用した.

同図(b)に，ユーザがシステムの前に立った際，身体に その温度分布情報がプロジェクタにより投影されている 様子を示す．鏡の向こう側であっても，対象である自身の 身体の 3 次元情報は失われておらず, ユーザは投影重畳さ れた温度分布を立体的に把握することができる。

一方, 同様の目的をモニタ上で熱画像を提示することで 実現しようとすると, 2 次元画像として観察することにな るために温度分布の立体的把握は不可能となる. また, モ 二タ上の熱画像から自分の身体の温度分布を把握するた めには，それぞれを交互に見て比較する必要があるが，先 述の通り，自身の身体を自分で見ることは困難な場合が多 い.

\section{5. 考察と今後の展望}

4.2 の基礎実験により, 提案した赤外線カメラ・プロジ エクタ・可視カメラの幾何学補正が有効であること, そし て, 色補正処理によって, 対象物体上のテクスチャの影響 を抑えて所望の色を投影面上で再現することが可能であ ることが確認できた。

現在は, 対象が動物体の場合では, 赤外線カメラとプロ ジェクタの光軸を同軸になるように設置しなければなら ない. しかし近年, 一度グレイコードパターン投影法で形 状計測を行った対象物体の動きを認識し, 追跡する研究が 行われており 8)，このような技術を利用することでこの制 約を解決することができると考えられる.また, 動物体を 対象とする場合に色補正処理が行えないという問題があ ったが，これも近年，一度較正処理を行なうだけで，投影 対象が動的な状況においても色補正処理を可能とする研 究が行われてきており, 今後改善することが可能であると 考えられる ${ }^{9)}$.
提案する投影型 MR 技術による対象物体への温度分布 重畳によって，2 章で述べた，モニタ上で熱画像を観察す るときに生じる問題点を解決できるかどうかを， $4.2,4.3$ での実験を通して考察する. 項目 1 の空間的な偏りのない シーンを対象とする場合に関しては，4.3(a)(b)の実験によ って, 同じ形をしているものが多く敷き詰められたシーン や真っ白の壁のような空間的に変化のない物体を対象と した場合に, モニタ上では温度分布と対象物体との幾何学 的対応が取れなかったのに対し，提案する手法では直観的 にそれを把握できることが示された. 項目 2 の対象物が立 体である場合に関しては，4.3の各実験において，立体感 を損なうことなく対象物体上に温度分布情報を提示する ことが可能であることが示されている. 項目 3 の対象物体 が動いている場合に関しては，4.2の基礎実験によって, 動いている対象に温度分布が位置ずれなく重畳されるこ とが示されている. 項目 4 の対象物体の温度分布を把握し ながら作業を行う場合に関しては, 4.3(a)の実験によって, ヘアドライヤから温風を対象物体に吹きつけながら, その 温度分布を観察する際に, ユーザは対象物体のみに注目し て操作を行うことができることが示されている. 項目 5 の 対面協調作業に関しては，4.3(c)で構築した作業環境が, モニタ上で情報を共有する環境に比べて, コンピュータ支 援のない通常の協調作業環境に近いことが示されている. 実物体を対話空間の中心に据える協調作業の重要性は, 実 物体を用いてデジタル世界とのインタラクションを提供 する Tangible User Interface の研究において示されてお り 10), このような観点からもユーザインタフェースの改 善が可能となったことが確認できた.

2 章の項目 1 のような状況としては, 他にも工場の電気 設備の保守やゴミ焼却場での異常検出といった場合が考 えられる. 工場の電気設備は, 老朽化によりケーブルや端 子に緩みが出て異常発熱を起こす場合があり, そのまま放 って置くと火災などを起こし, 大事故につながる原因とな る. その異常の多くが発熱として表れるため, 定期的な熱 画像を利用した点検によって, 異常箇所の早期発見が可能 となる.しかし, こういった電気設備は, 配電盤内のレバ 一やボタンなど, 同形状のものが整然と並んでいることが 多く, その中から異常加熱している部分の位置を把握する ことはモニタ上では困難となる. 提案システムによって, 異常過熱部位を即座に同定することができ, 早急に処置を 行うことができる. 同様に, ゴミ焼却場でベルトコンベア で運ばれてくるゴミの中から異常発熱しているものを見 つけるといった応用も考えられる. ベルトコンベア上のゴ ミは雑多で, ユーザは異常発熱をモニタ上で確認しても, それがどこなのかを即座に判断することは困難である. 提 案システムを用いれば，直観的に異常部分を特定でき，大 事故を未然に防ぐことができる.

4.3(d)で示した人体への温度分布の投影重畳は, 自身の 
健康チェックだけでなく, 医療現場での利用も可能である と考えられる。これまでは，モニタ上で観察するしかなか った患者の体表温度を, 医師が患者の身体の上でより直観 的に把握することができるようになる．また，4.3(c)で示 した対面協調作業環境と組み合わせることで, 医師と患者 との問診中のコミュニケーションを促進することもでき る.つまり, 患者の身体の問題のある部位に投影された温 度分布をお互いに確認しながら, 医師は患者にその問題に ついて説明することができ, 患者は病気に対する理解を深 めることが可能となる.

\section{6. おわりに}

本研究では，投影型 $\mathrm{MR}$ 技術を基に，熱画像を対象物 体に直接投影して温度分布を可視化する手法を提案した。 対象物体上に温度分布を正確に位置合わせして投影する ための幾何学補正手法と, 対象表面の反射特性や環境光の 影響を受けず任意の色を投影表示する色補正手法を提案 し，基礎実験によってその有効性を確認した４ 種の応用 実験を行い, モニタ上で温度分布を確認する際の問題点を 解決できることを示した. 今後は, 今回提案した手法を応 用し，他の特殊画像 (X 線画像や超音波画像) に関しても 対象物体に直接投影することで, ユーザインタフェースの 観点からの可視化システムの改善を目指す.

\section{参 考 文 献}

1) Burnay, S.G., Williams, T. L., Jones, C.H. N. : Applications of Thermal Imaging, Adam Hilger (1988).

2) Billinghurst, M., Kato, H. : Collaborative augmented reality, Communications of the ACM, Vol.45, No. 7 (2002) pp. 64-70.

3）清川清, マーク・ビリングハースト, ダニエル・ベルチャ, アルナブ・グプタ : 拡張現実感インタフェースを用いた対面 協調作業のコミュニケーション過程, 日本バーチャルリア リティ学会論文誌, Vo17, No.2（2002）pp. 159-168.

4) 井口征士, 佐藤宏介 : 三次元画像計測, 昭晃堂 (1990).

5）東城賢司，日浦慎作，井口征士:プロジェクタを用いた 3 次 元遠隔指示インタフェースの構築, 日本バーチャルリアリ ティ学会論文誌, Vol. 7, No. 2（2002）pp. 169-176.

6) 吉田壮伸, 堀井千夏, 佐藤宏介 : 複合現実感のための反射色 計測に基づくプロジェクタ投影テクスチャ，日本バーチャ ルリアリティ学会論文誌，Vol. 9, No. 1（2004）pp. 97-104.

7）高橋成治：TWI パルス式サーモグラフィ非破壊検查装置 EchoTherm, 画像ラボ, 日本工業出版, Vo1.16, No. 8 (2005) pp. 24-27.

8）森谷貴行, 日浦慎作, 佐藤宏介 : 多視点画像と CG 画像の比 較に基づく動物体の運動計測, 電子情報通信学会論文誌, Vol. J88-D-II, No. 5 (2005) pp. 876-885.

9) Fujii, K., Grossberg, M. D., Nayar, S. K. : A Projector-Camera System with Real-Time Photometric Adaptation for Dynamic Environments, Proceedings of CVPR'05, IEEE, Vo1. 1 (2005) pp. 814-821.

10) Ishii, H., Ul1mer, B. : Tangible bits: towards seamless interfaces between people, bits and atoms, Proceedings of CHI'97, ACM (1997) pp. 234-241. 